Section Editor

Robert C. Griggs, MD
Editors' Note: Dr. Sethi discusses the disproportionate allocation of resources to neurologic diseases' treatment compared to primary prevention. Focusing on the latter would do greater good for the greatest number of people. Dr. Silberberg agrees and mentions another study that supports this view. Dr. Beran criticizes Braley et al., pointing out that in their sleep-disordered breathing in multiple sclerosis (MS) study, they did not include an analysis of the impact of periodic limb movement (PLM) on sleep. Braley et al. reviewed their data and found no correlation between PLM and increased daytime sleepiness in patients with MS.

Chafic Karam, MD, and Robert C. Griggs, MD

\section{BRAIN DISORDERS WHERE RESOURCES ARE SCARCE: THE UNFINISHED AGENDA}

Nitin K. Sethi, New York: I read Dr. Silberberg's ${ }^{1}$ recent commentary with interest. Neurologic and psychiatric disorders can overwhelm medical services in the underdeveloped and developed world where the burden of infectious diseases is high. Diseases such as malaria, tuberculosis, and cholera carry high morbidity and mortality rates and consume health care resources. Neurologic conditions such as stroke and epilepsy are pushed lower on the government's health priority lists. We recently reported on another disturbing trend. ${ }^{2}$

In India, there is a disproportionate allocation of resources to stroke treatment with costly interventions such as recombinant tissue plasminogen activator and mechanical embolectomy by establishing stroke centers in large state and central government hospitals rather than stroke prevention via stroke risk factor modification in the masses. Only those who live in the big cities benefit from such intervention, whereas stroke risk factor modification has the potential to benefit a majority of those residing in small towns and villages with limited access to health care resources.

Neurocysticercosis remains the most common cause of new-onset epilepsy among the young in India. It can be eradicated only via education and improved sanitation practices, not costly anticonvulsants that only a privileged few in these countries can afford. The burden of brain disorders in these countries can only be reduced if the limited available resources are used efficiently with emphasis on primary and secondary prevention of stroke, epilepsy, and infectious neurologic diseases. Policymakers in these countries should remember the goal of medicine should always be to do the greatest good for the greatest number of people.

Author Response: Donald H. Silberberg, Philadelphia: I enjoyed reading Dr. Sethi's remarks, and fully agree that prevention is far preferable to treatment or rehabilitation whenever possible. His points are made even more relevant by the recent study of adult deaths in rural southern Tanzania. Narh-Bana et al. ${ }^{3}$ found that epilepsy and stroke ranked among the top 5 causes of death, responsible for $21 \%$ of adult mortality. It is probable that a similar situation exists throughout Sub-Saharan Africa-that the vast majority of noncommunicable disease deaths are from neurologic disorders.

(C) 2013 American Academy of Neurology

1. Silberberg D. Brain disorders where resources are scarce: the unfinished agenda. Neurology 2012;79:1285-1287.

2. Sethi PK, Sethi NK. Lest we forget: the other 97\%. IJS (in press 2013).

3. Narh-Bana SA, Chirwa TF, Mwanyangala MA, Nathan R. Adult deaths and the future: a cause-specific analysis of adult deaths from a longitudinal study in rural Tanzania 2003-2007. Trop Med Int Health 2012;17:1365-3156

\section{SLEEP-DISORDERED BREATHING IN MULTIPLE SCLEROSIS}

Roy G. Beran, Chatswood, Australia: Braley et al. ${ }^{1}$ investigated sleep-disordered breathing in multiple sclerosis (MS) using overnight polysomnography. MS produced increased apnea-hypopnea index (AHI) and central apnea index (CAI). Periodic limb movement in sleep (PLMS) with associated periodic limb movement causing arousal (PLMA) was not addressed by the authors.

A pilot study showed that patients with MS with excessive sleepiness-also interpreted as fatiguehad significantly elevated PLMA compared to controls with and without MS. ${ }^{2}$ Despite small numbers, 6 in each arm, this study demonstrated statistically significant differences between MS with and without excessive sleepiness. It is disappointing that the authors ignored this finding. The data should still be available and PLMS with PLMA should be analyzed 


\section{Neurology}

\section{Brain disorders where resources are scarce: The unfinished agenda \\ Nitin K. Sethi and Donald H. Silberberg \\ Neurology 2013;80;1354 \\ DOI 10.1212/WNL.0b013e31828cf4b9}

\section{This information is current as of April 1, 2013}

Updated Information \& Services

References

Permissions \& Licensing

Reprints including high resolution figures, can be found at: http://n.neurology.org/content/80/14/1354.1.full

This article cites 2 articles, 1 of which you can access for free at: http://n.neurology.org/content/80/14/1354.1.full\#ref-list-1

Information about reproducing this article in parts (figures,tables) or in its entirety can be found online at:

http://www.neurology.org/about/about_the_journal\#permissions

Information about ordering reprints can be found online:

http://n.neurology.org/subscribers/advertise

Neurology ${ }^{\circledR}$ is the official journal of the American Academy of Neurology. Published continuously since 1951 , it is now a weekly with 48 issues per year. Copyright @ 2013 American Academy of Neurology. All rights reserved. Print ISSN: 0028-3878. Online ISSN: 1526-632X.

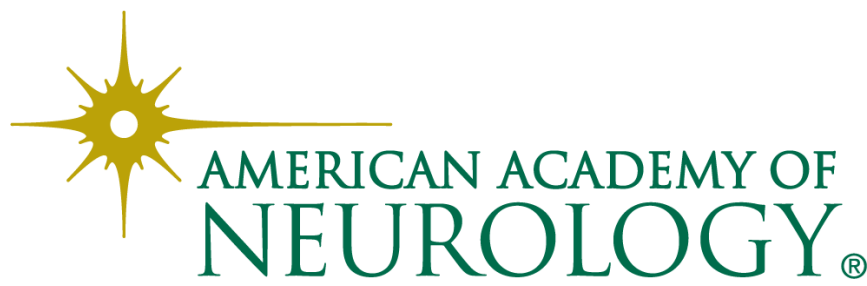

